\title{
Description of two new actinosporean types from a brook of Fuji Mountain, Honshu, and from Chitose River, Hokkaido, Japan
}

\author{
Csaba Székely ${ }^{1, *}$, Hiroshi Yokoyama ${ }^{3}$, Shigehiko Urawa ${ }^{2}$, Tarmo Timm ${ }^{4}$, Kazuo Ogawa $^{3}$ \\ ${ }^{1}$ Veterinary Medical Research Institute, Hungarian Academy of Sciences, Hungaria krt. 21, 1143 Budapest, Hungary \\ ${ }^{2}$ National Salmon Resources Center, Fisheries Agency of Japan, 2-2 Nakanoshima, Toyohira-ku Sapporo, 062-0922 Japan \\ ${ }^{3}$ Department of Aquatic Bioscience, The University of Tokyo, Yayoi 1-1-1, Bunkyo-ku, Tokyo 113-8657, Japan \\ ${ }^{4}$ Institute of Zoology and Botany at the Estonian Agricultural University, Limnological Station, 61101 Rannu, Tartumaa, Estonia
}

\begin{abstract}
Actinospore infection of oligochaetes living in the mud of 3 freshwater biotopes in Japan was studied. Using the cell-well plate method, a new aurantiactinomyxon type was found in $0.77 \%$ of the examined Tubifex tubifex oligochaete specimens from a brook near Yamanashi Prefectural Fisheries Experimental Station on Fuji Mountain. In $0.14 \%$ of Lumbriculus variagetus collected from Chitose River, near Chitose Salmon Hatchery, a new siedleckiella type was found, while at the same time $8.1 \%$ of the Lumbriculus spp. oligochaetes released triactinomyxons of Myxobolus arcticus. Of the examined Rhyacodrilus komarovi oligochaetes collected from the Mena River system, Hokkaido, $0.2,0.6,0.5$ and $0.8 \%$ were infected with echinactinomyxon, neoactinomyxum and 2 types of triactinomyxon spores, respectively, and described in our previous paper. The oligochaetes released actinospores for several weeks. Actinospore infection showed high intensity in positive oligochaetes in the case of all the actinosporean types. Two of the actinospore types (aurantiactinomyxon and siedleckiella) presented here have not been previously described.
\end{abstract}

KEY WORDS: Aurantiactinomyxon · Siedleckiella · Actinospore $\cdot$ Myxospore $\cdot$ Tubifex tubifex Lumbriculus variegatus $\cdot$ Oligochaete alternate hosts · Japan

\section{INTRODUCTION}

The first report on actinospores described these organisms as parasites related to myxosporeans (Štolc 1899). For a long time this group of parasites was believed to represent an independent taxonomic entity. Research on actinosporeans became more intensive after Wolf \& Markiw (1984) proved that they correspond to the intraoligochaete developmental stages of fish-parasitic myxosporeans (Kent et al. 2001). The relevant research includes earlier surveys (Janiszewska 1955, 1957, Ormieres \& Frezil 1969, Marques 1984), as well as studies of actinospore infection of oligochaetes in natural waters and fish farms in connection with the life cycle of myxosporeans (Kent et al. 2001). The main objective of this work was to describe the actinospore stages of myxosporeans from a biotope on Fuji Mountain and from 2 biotopes on Hokkaido.

\section{MATERIALS AND METHODS}

Survey. The survey investigated actinosporeans from 3 biotopes. (1) From a brook in Yamanashi Village on Fuji Mountain, Honshu, near Yamanashi Prefectural Fisheries Experimental Station. In this biotope mainly salmonid fishes can be found such as brown trout Salmo trutta or rainbow trout Onchorhynchus mykiss. Other abundant fish species living in the stream are oikawa Zacco platypus, iwana Salvelinus leucemaensis and bullhead Ictalurus sp. (2) From Chitose River, Hokkaido, near the largest salmon hatchery in Hokkaido. The most abundant fishes were salmonids, e.g. masu salmon Onchorhynchus masou, chinook salmon $O$. tshawytscha and chum salmon $O$. keta. (3) From an inflow brook of a salmon hatchery in the Mena River system on Hokkaido, where the most abundant fishes were also salmonids. A previous sam- 
pling was already performed from this biotope (Székely et al. 2002).

Samplings were conducted from all of the 3 biotopes in the second part of April 2001 at the time of the melting of snow, at a water temperature of 4 to $6^{\circ} \mathrm{C}$. To detect the intraoligochaete actinospore types, the oligochaetes were washed out from the mud and from organic matter accumulated at the bottom of the brooks and river with a close-meshed net, placed into a small amount of water in a plastic collection dish and transported to the University of Tokyo (Fuji sample) or to the Sapporo Laboratory of the National Salmon Resources Center (Hokkaido samples). After collection, the oligochaetes were individually placed into wells of cell-well plates (Yokoyama et al. 1991). Before replacing the lid, the plates were covered with selfadhesive plastic foil to prevent the worms from crawling out. Starting from the next day, the water layer above each oligochaete in each of the wells was regularly examined for the presence of released actinospores. The plates were kept in a refrigerator at $4^{\circ} \mathrm{C}$ throughout the study, and the water in the wells was changed once or twice a week, as needed. On the day after collection in Hokkaido the oligochaetes were transported to the University of Tokyo, where they were examined for an additional $10 \mathrm{~d}$. They were then transported to Hungary, and monitored for actinospore release for an additional $2 \mathrm{mo}$, up to the death of the last worm.

If the examination by stereo microscope indicated spore release, the actinospores floating in, or adhering to, the wells of the cell-well plates were examined on a slide by light microscopy at higher magnifications, then microphotographs were taken of the spores using a conventional microscope with photographic attachment and a digital microscope camera. Subsequently, drawings were made of the actinospores and their measurements were taken. The characteristic dimensions of actinospores (polar capsules, spore body, caudal processes) and number of infective cells were recorded by measuring newly released spores according to the guidelines suggested by Lom et al. (1997). To determine the dimensions of actinospores, measurements of 30 mature spores were averaged. From all examined biotopes some of the infected oligochaetes were fixed in $80 \%$ ethanol and identified in Estonia as described by Timm (1997).

Infection experiment. Experimental infection of uninfected Masu salmon Onchorhynchus masou fingerlings was carried out with a new actinospore type found in Lumbriculus variegatus collected from the Chitose River. Eight fingerlings were immersed for $4 \mathrm{~h}$ to a 21 tank containing ca. $10^{4}$ floating siedleckiellaspores. Masu salmon fingerlings were kept in a flowtrough tank and dissected after 9 mo post experiment, and all the organs were checked in smear preparations for the presence of myxospores.

\section{RESULTS}

\section{Survey}

Fuji Mountain brook

Of the 130 examined oligochaetes from Fuji Mountain (Tubifex tubifex, Rhyacodrilus coccineus, Dero digitata and Limnodrilus hoffmeisteri), only $1 \mathrm{~T}$. tubifex specimen $(0.77 \%)$ proved to be infected with a new aurantiactinomyxon type (Figs. 1 to 5). The release of the aurantiactinospores was very rapid - all the spores were released into the lumen of the cell-well plate on the first day after collection. No further actinospores were found to be released during the 2 mo observation period.

\section{Chitose river}

Fifty-five of the 680 collected Lumbriculus variegatus oligochaetes ( $8.1 \%$ ) proved to be infected with the wellknown triactinospores of Myxobolus arcticus, the brain parasite of salmonids (Kent et al. 1993, Urawa 1994). The oligochaetes released a total of ca. 75000 triactinospores in $2 \mathrm{~d}$. Only 1 of the $680 \mathrm{~L}$. variegatus $(0.15 \%)$ released a new siedleckiella type on the first day after collection (Figs. 6 to 10). No further new actinospore types were released during the 2 mo observation period.

\section{Infection experiment}

No infection developed in Masu salmon fingerlings exposed to siedleckiella spores.

\section{Mena River system}

Out of the 620 Rhyacodrilus komarovi specimens collected from the Mena River system, 16 specimens proved to be infected with the same actinospore types as those
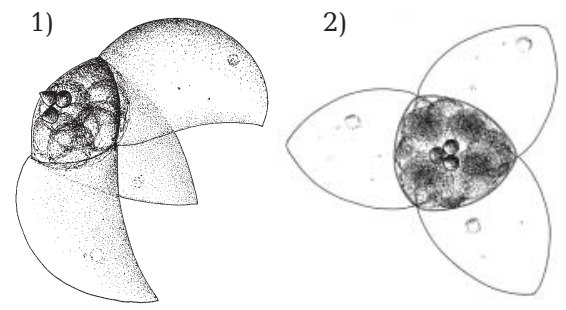

Figs. $1 \& 2$. Schematic drawings of the aurantiactinomyxon type actinospores. Fig. 1. Side view. Fig. 2. Apical view 

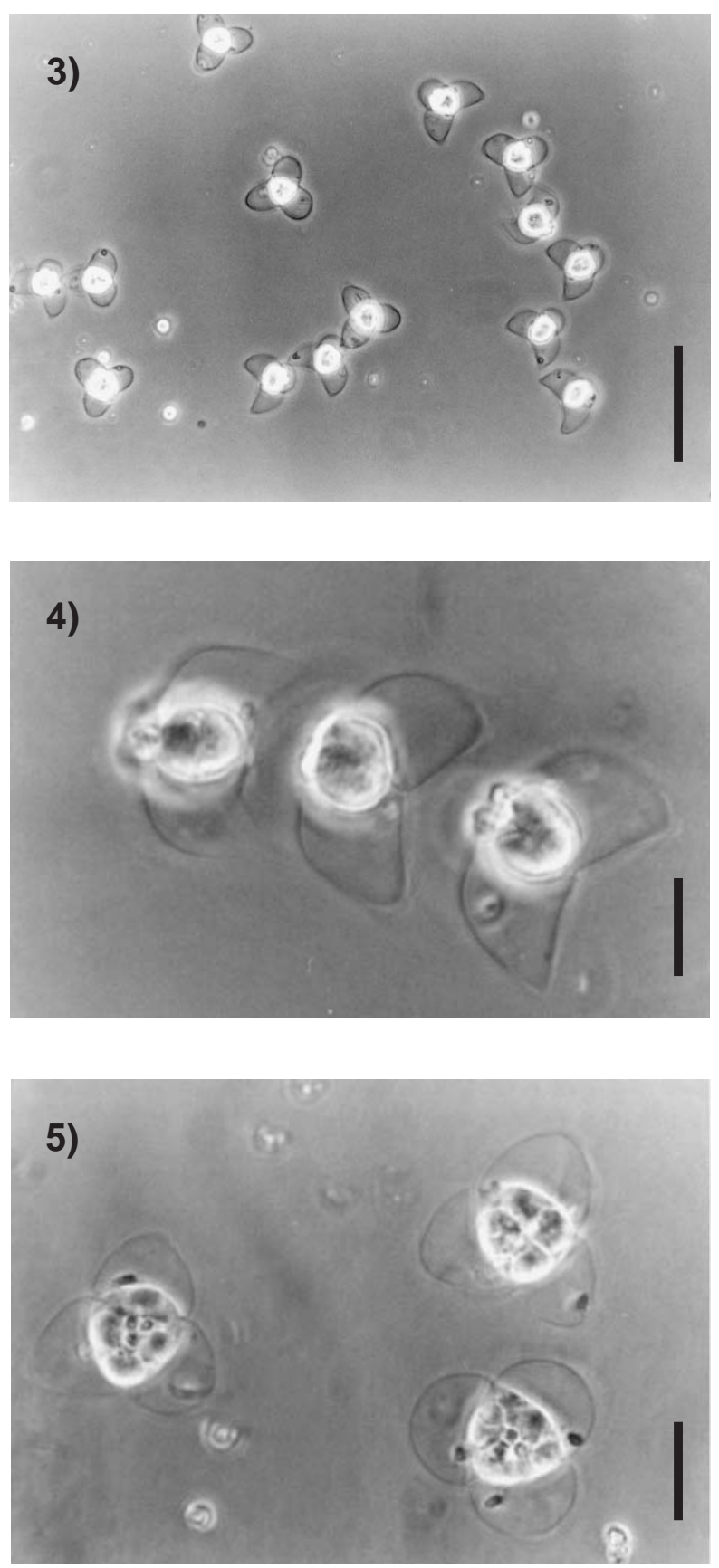

Figs. 3 to 5. Aurantiactinomyxon type actinospores released from an infected Tubifex tubifex, under a coverslip, from a brook in Fuji Mountain, Honshu. Fig. 3. Freshly released floating actinospores (scale bar $=35 \mu \mathrm{m}$ ). Fig. 4 . Side view of actinospores (scale bar $=10 \mu \mathrm{m}$ ). Fig. 5. Apical view of actinospores (scale bar $=12.5 \mu \mathrm{m}$ ). Note the 3 polar capsules and the short caudal processes

described in our previous paper (Székely et al. 2002). The prevalence of infection by these echinactinomyxon, neoactinomyxum and 2 types of triactinomyxon was 0.2 , $0.6,0.5$ and $0.8 \%$, respectively, during the 2 mo survey.
The oligochaetes kept individually in the wells of the cell-well plates released actinospores $24 \mathrm{~h}$ after collection. However, spore release from the isolated oligochaete specimens was not synchronous, as some oligochaetes released mature spores only 7 to $10 \mathrm{~d}$ after collection, while others did so between $2 \mathrm{wk}$ and 2 mo after collection.

\section{Description of the 2 new actinospore types}

One of the detected new actinospores proved to be an aurantiactinomyxon (Figs. 1 to 5), and another represented a siedleckiella (Figs. 6 to 10) type. The most important parameters of the 2 new types are presented in Tables $1 \& 2$.

\section{DISCUSSION}

Based upon their dimensions (presented in Tables 1 and 2), the 2 actinomyxon types found during this survey show the following relationship with the types described in the literature so far.

\section{Aurantiactinomyxon}

Aurantiactinomyxon types, or as the alternative spore forms of myxosporeans, have already been described by the following authors: Janiszewska (1955), Ormieres \& Frézil (1969), Marques (1984), El-Matbouli et al. (1992), Grossheider \& Körting (1992), Benajiba \& Marques (1993), Pote \& Waterstrat (1993), Yokoyama et al. (1993), Troullier et al. (1996), McGeorge et al. (1997), Yokoyama (1997), El-Mansy et al. (1998a,b), Székely et al. (1998, 2000), Negredo \& Mulcahy (2001).
6)

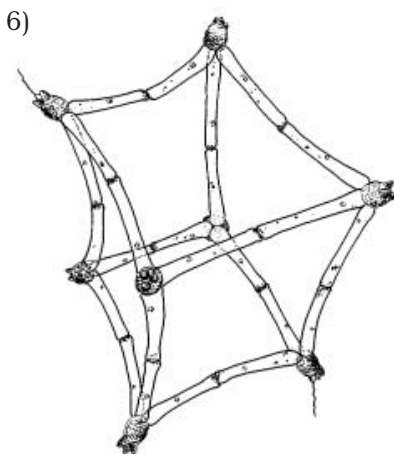

7)

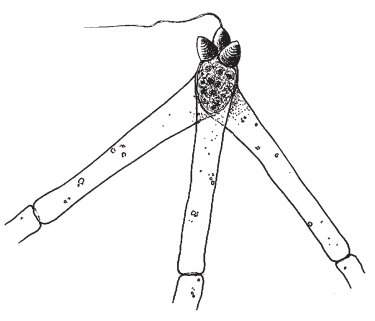

Figs. $6 \&$ 7. Schematic drawings of the siedleckiella type actinospores. Fig. 6. Three-dimensional cube-shaped reticulation of 8 siedleckiella actinospores. Eight spores form a 3-dimensional cube-shaped reticulation, each spore joining the processes of 3 different spores. Sporoplasm barrel-shaped.

Fig. 7. Single siedleckiella actinospore 

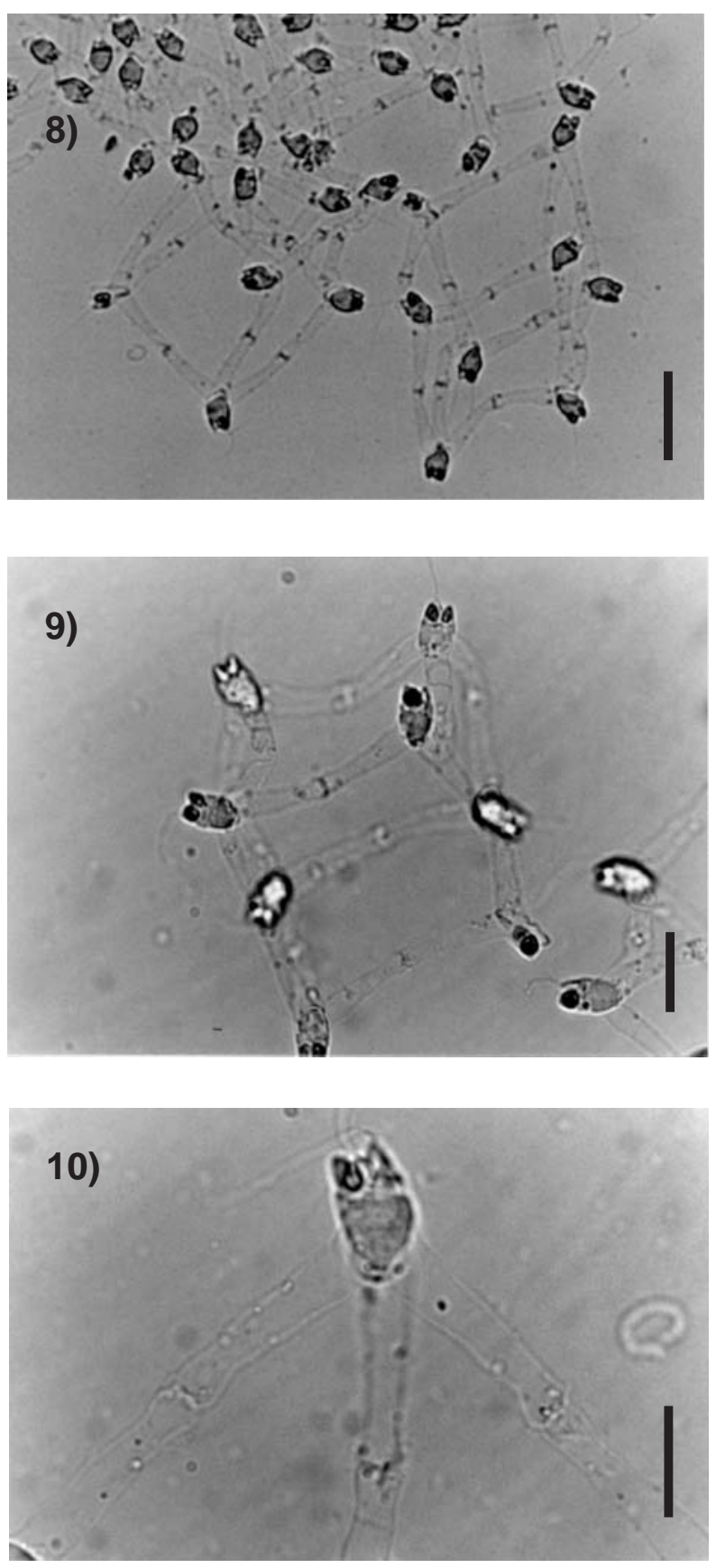

Figs. 8 to 10. Siedleckiella type actinospores infecting Lumbriculus variegatus collected in Chitose River, Hokkaido. Figs. $8 \& 9$. Three-dimensional cube-shaped reticulation of the siedleckiella type actinospores (scale bar $=15$ and $10 \mu \mathrm{m}$, respectively). Fig. 10. Enlarged actinospore (scale bar $=5 \mu \mathrm{m}$ )

The aurantiactinomyxon type detected here differs substantially from those above in 1 of its dimensions. An exception is the species (type) described by Ormieres \& Frézil (1969) as Aurantiactinomyxon eiseniellae, which is identical to the actinospore found here in both spore diameter $(12 \mu \mathrm{m}$ [Ormieres \& Frézil's data], $13.5 \mu \mathrm{m}$ [our data]) and caudal process length $(10-15 \mu \mathrm{m}, 12.4 \mu \mathrm{m})$. However, the sporoplasm of $A$. eiseniellae contains 32 secondary cells while ours contains only 8 ; the caudal processes of $A$. eiseniellae are ball-like, spherical, while the aurantiactinomyxonspore caudal processes found here are shaped like an equilateral triangle. The actinospore described by Yokoyama et al. (1993) from Branchiura sowerbyi as neoactinomyxon also greatly resembles the aurantiactinospore type found here in its dimensions (spore cavity diameter: $16 \mu \mathrm{m}$ [Yokoyama et al.'s data], $13.5 \mu \mathrm{m}$ [our data], caudal process length: $10 \mu \mathrm{m}$, $12.4 \mu \mathrm{m})$. Yokoyama et al. (1993) regards neoactinomyxon as a possible alternative actinospore of Hoferellus carassii causing kidney enlargement disease of goldfish. However, the caudal processes of this actinospore are semicircular in apical view, while those of the new type are more like a triangle. The aurantiactinomyxon found here is not identical to the types described previously in the literature.

\section{Siedleckiella (Antonactinomyxon)}

The siedleckiella found here is not identical to the types described previously in the literature either. Only 4 types of siedleckiella (or antonactinomyxon) have been described in the literature so far. Janiszewska (1957) described Siedleckiella silesica from Tubifex sp. and $S$. antonii from Limnodrilus claparedeanus parasitising the gut epithelium of the above oligochaetes from the Odra River, Poland. Both types (described as species) are 10 to 15 times larger than the siedleckiella type found here. Uspenskaya (1995)

Table 1. Measurements of the aurantiactinomyxon-type actinospores detected during the survey from Tubifex tubifex collected at the Fuji Mountain, Honshu ( $\mu \mathrm{m}$, average of 30 spores)

\begin{tabular}{|llc|}
\hline & & $\begin{array}{c}\text { Measurement } \\
\text { (range) }\end{array}$ \\
\hline $\begin{array}{c}\text { Polar capsules } \\
\text { (side view) }\end{array}$ & Length & 2.0 \\
Number of infective & Width & 1.0 \\
cells (approx.) & & 8 \\
$\begin{array}{c}\text { Diameter of spore } \\
\text { body (side view) }\end{array}$ & Length (side view) & $12.4(10-14)$ \\
$\begin{array}{c}\text { Caudal processes } \\
\text { Largest span }\end{array}$ & Width (side view) & $12.4(12-13)$ \\
between the ends of & Width (apical view) & $13.5(13-14)$ \\
the caudal processes & $26.8(25-30)$ \\
\hline
\end{tabular}


Table 2. Measurements of the siedleckiella (antonactinomyxon)-type actinospores released by Lumbriculus variegatus collected in Chitose River, Hokkaido $(\mu \mathrm{m}$, average of 30 triactinospores). nd: not determined

\begin{tabular}{|llc|}
\hline & & $\begin{array}{c}\text { Measurement } \\
\text { (range) }\end{array}$ \\
\hline Polar capsules & $\begin{array}{l}\text { Length } \\
\text { Width }\end{array}$ & $\begin{array}{c}2.4(2-3) \\
\text { nd } \\
\text { nd }\end{array}$ \\
$\begin{array}{llc}\text { Number of infective } \\
\text { cells (approx.) }\end{array}$ & & \\
Sporoplasm & Length & $7.7(7-9)$ \\
& Width & $4.5(4-5)$ \\
Caudal processes & Length & $12.9(12-15)$ \\
& Width (at the base) & $3.3(3-4)$ \\
& Width (at the joint) & $2.2(2.0-2.5)$ \\
\hline
\end{tabular}

experimentally obtained a siedleckiella-like actinospore in T. tubifex, when she infected the oligochaetes with Zschokkella nova myxospores collected from Carassius carassius. This actinospore is 5 times larger than the type found here. Another difference is the short style of the spores found by Uspenskaya (1995), while our type is styleless. Xiao \& Desser (1998) described an antonactinomyxon (siedleckiella) type from T. tubifex collected in Lake Sasajewun, Ontario. In this type, 8 spores form a 3D reticulation. This antonactinomyxon resembles our siedleckiella type, but its size is 10 times larger and the connection between the spores is also different. Siedleckiella spores may have another host than Masu salmon, because the infection experiments proved to be negative.

Experts in the systematics of myxosporeans disagree with the description of new actinospore types detected from oligochaetes. According to Kent \& Lom (1999), actinospores detected from oligochaetes should be regarded as developmental stages of Myxozoa species parasitising vertebrate hosts, primarily fish, whereas Lester et al. (1998) are of the opinion that new species of Myxozoa can be described as based solely on the actinospores. Considering their arguments, we accept the guidelines provided by Kent \& Lom (1999), and describe new actinospores only as types in every case. Their description as species should be based on the production of myxospores experimentally obtained in the vertebrate host or on their identification by molecular biological methods.

Based upon the features described in the differential diagnoses, 2 out of the 7 actinospore types detected in this study appear to be new forms hitherto not described in the literature. The possible relation of these actinospore forms to other myxosporean species could be estimated by infection experiments or by the use of molecular biological techniques; these, however, have not been carried out so far.
Acknowledgements. The authors wish to thank the JSPSHungarian Academy Agreement (No. 26) and the Hungarian Scientific Research Fund (OTKA) contracts no. T 031755 and 029200, which allowed us to work on this project. We also thank Dr. Gábor Majoros for the pencil-drawings.

\section{LITERATURE CITED}

Benajiba MH, Marques A (1993) The alternation of actinomyxidian and myxosporidian sporal forms in the development of Myxidium giardi (parasite of Anguilla anguilla) through oligochaetes. Bull Eur Assoc Fish Pathol 13:100-103

El-Mansy A, Székely Cs, Molnár K (1998a) Studies on the occurrence of actinosporean stages of fish myxosporeans in a fish farm of Hungary, with the description of triactinomyxon, raabeia, aurantiactinomyxon and neoactinomyxon types. Acta Vet Hung 46:259-284

El-Mansy A, Székely Cs, Molnár K (1998b) Studies on the occurrence of actinosporean stages of myxosporeans in Lake Balaton, Hungary, with the description of triactinomyxon, raabeia and aurantiactinomyxon types. Acta Vet Hung 46: $437-450$

El-Matbouli M, Fischer-Scherl T, Hoffmann R (1992) Transmission of Hoferellus carassii Achmerov, 1960 to goldfish Carassius auratus via an aquatic oligochaete. Bull Eur Assoc Fish Pathol 12(2):54-56

Grossheider G, Körting W (1992) First evidence that Hoferellus cyprini (Doflein, 1898) is transmitted by Nais sp. Bull Eur Assoc Fish Pathol 12(1):17-20

Janiszewska J (1955) Actinomyxidia: morphology, ecology, history of investigations, systematics, development. Acta Parasitol Pol 2:405-443

Janiszewska J (1957) Actinomyxidia II. New systematics, sexual cycle, description of new genera and species. Zool Pol 8:3-34

Kent M, Lom J (1999) Can a new species of Myxozoa be described based solely on their actinosporean stage? Parasitol Today 15:472-473.

Kent ML, Whitaker DJ, Margolis L (1993) Transmission of Myxobolus arcticus Pugachev and Khokhlov, 1979, a myxosporean parasite of Pacific salmon, via a triactinomyxon from the aquatic oligochaete Stylodrilus heringianus (Lumbriculidae). Can J Zool 71: 1207-1211

Kent ML, Andree KB, Bartholomew JL, El-Matbouli M and 12 others (2001) Recent advances in our knowledge of the myxozoa. J Eukaryot Microbiol 48:395-413

Lester RJG, Hallett SL, El-Matbouli M, Canning EU (1998) The case for naming actinosporeans using the Zoological Code. Parasitol Today 14:476-477

Lom J, McGeorge J, Feist SW, Morris D, Adams A (1997) Guidelines for the uniform characterisation of the actinosporean stages of parasites of the phylum Myxozoa. Dis Aquat Org $30: 1-9$

Marques A (1984) Contribution á la connaissance des Actinomyxidies: ultrastructure, cycle biologique, systematique. $\mathrm{PhD}$ thesis, Univ des Sciences et Techniques du Languedoc, Montpellier

McGeorge J, Sommerville C, Wootten R (1997) Studies of actinosporean myxozoan stages parasitic in oligochaetes from sediments of a hatchery where Atlantic salmon harbour Sphaerospora truttae infection. Dis Aquat Org 30:107-119

Negredo C, Mulcahy MF (2001) Actinosporean infections in oligochaetes in a river system in southwest Ireland with descriptions of 3 new forms. Dis Aquat Org 46:67-77

Ormieres R, Frezil JL (1969) Aurantiactinomyxon eiseniellae n. sp., Actinomyxidie Parasite d'Eiseniella tetraedra Sav. (Oligochaeta - Lumbricidae). Protistologica 1:137-144 
Pote LM, Waterstrat P (1993) Motile stage of Aurantiactinomyxon sp. (Actinosporea: Triactinomyxidae) isolated from Dero digitata found in channel catfish ponds during outbreaks of proliferative gill disease. J Aquat Anim Health 5: $213-218$

Štolc A (1899) Actinomyxidies, nouveau groupe de Mesozoaires parent des Myxosporidies. Bull Int Acad Sci Boheme 22:1-12

Székely Cs, El-Mansy A, Molnár K, Baska F (1998) Development of Thelohanellus hovorkai Achmerov, 1960 and Thelohanellus nikolskii Achmerov, 1955 (Myxosporea: Myxozoa) in oligochaete alternate hosts. Fish Pathol 33:107-114.

Székely Cs, Sitja-Bobadilla A, Alvarez-Pellitero P (2000) First report on the occurrence of an actinosporean stage (Myxozoa) in oligochaetes from Spanish freshwaters. Acta Vet Hung 48: 433-441

Székely C, Urawa S, Yokoyama H (2002) Occurrence of actinosporean stages of myxosporeans in an inflow brook of a salmon hatchery in the Mena River System, Hokkaido, Japan. Dis Aquat Org 49:153-160

Urawa S (1994) Life cycle of Myxobolus arcticus, a myxosporean parasite of salmonid fishes. Book of Abstracts. Int Symp on Aquatic Animal Health, Seattle, 4-8 September 1994. P-W-10.3

Uspenskaya AV (1995) Alternation of actinosporean and myxosporean phases in the life cycle of Zschokkella nova (Myxozoa). J Eukaryot Microbiol 42:665-668

Timm T (1997) Freshwater Oligochaeta of some urban watercourses in the Russian Far East. Int Rev Gesamt Hydrobiol 82:437-467

Editorial responsibility: Wolfgang Körting,

Hannover, Germany
Troullier A, El-Matbouli M, Hoffmann W (1996) A new look at the life cycle of Hoferellus carassii in the goldfish (Carassius auratus) and its relation to 'kidney enlargment disease' (KED). Folia Parasitol 43:173-187

Wolf K, Markiw ME (1984) Biology contravenes taxonomy in the Myxozoa: new discoveries show alternation of invertebrate and vertebrate hosts. Science 225:1449-1452

Xiao C, Desser SS (1998) Actinosporean stages of myxozoan parasites of oligochaetes from Lake Sasajewun, Algonquin Park, Ontario: new forms of echinactinomyxon, neoactinomyxum, aurantiactinomyxon, guyenotia, synactinomyxon and antonactinomyxon. J Parasitol 84: 1010-1019

Yokoyama H (1997) Transmission of Thelohanellus hovorkai Acmnerov, 1960 (Myxosporea: Myxozoa) to common carp, Cyprinus carpio, through the alternate oligochaete host. Syst Parasitol 36:79-84

Yokoyama H, Ogawa K, Wakabayashi H (1991) A new collection method of actinosporeans - a probable infective stage of myxosporeans to fishes - from tubificids and experimental infection of goldfish with the actinosporean, Raabeia sp. Fish Pathol 26:133-138

Yokoyama H, Ogawa K, Wakabayashi H (1993) Involvement of Branchiura sowerbyi (Oligochaeta: Annelida) in the transmission of Hoferellus carassii (Myxosporea: Myxozoa), the causative agent of kidney enlargement disease (KED) of goldfish Carassius auratus. Fish Pathol 28: 135-139

Submitted: February 18, 2002; Accepted: August 25, 2002 Proofs received from author(s): January 8, 2003 